\title{
ПАРИЖ БАРОНА ОСМАНА: СТОЛИЦА НА ПУТЯХ ОТ ГОРОДА ЭПОХИ КУЛЬТУРЫ К ГОРОДУ ЭПОХИ ЦИВИЛИЗАЦИИ В ЗЕРКАЛЕ ЛИТЕРАТУРЫ И ИСКУССТВА
}

\begin{abstract}
Аннотация: B статье исследуется отражение радикального обновления одного из старейших городов Европы, столииы Франиии Парижа, предпринятого бароном Османом в 1850-х - 1900-х годах, в литературе ХІХ века (на примере произведений Э. Золя, Ги де Мопассана, В. Гюго, Ш. Бодлера). Значение его состоит в превращении города как средоточия традиционной культуры в передовой цеентр индустриальной циивилизации. Цель данной статьи - проследить связь, которая существовала между перепланировкой города и созданием новых правил иивилизованного общежития, изучить реакиию на произошедшие изменения в искусстве, а именно в литературе. Османовский Париж явился образиом тотальной перестройки города в индустри-альную эпоху, в эпоху формирования массового общества. Несмотря на ту разрушительную силу, которую нес с собой Осман, несмотря на уничтожение им исторических памятников и изменение атмосферы, иаривщей в Париже того времени и столь иенимой современниками, его позитивное влияние на развитие города неоспоримо. В ходе исследования отклика на реформы Османа в искусстве открылась диалектика культурного движения, которая разрешила конфликт между старым и новым. Первое неприятие произведенных изменений сменяется двумя тенденциями: во-первых, с новой силой открывается ценность старого, ставится проблема сохранения прошлого, возобновляется интерес к истории; во-вторых, новое становится повседневностью, входит в интимный мир человека, поэтизируется и включается в культурный контекст эпохи.

Review: The author of the article studies how radical transformation of one f the oldest cities in Europe and the capital of France, Paris, made by Baron Haussmann in the 1850's - 1900's, was reflected in literature at XIX century (based on the example of Emile Zola, Guy de Maupassant, Viktor Hugo and Charles Baudelaire). The main idea of transformations was to turn the city as the centre of traditional culture into a progressive center of industrialized civilization. The purpose of the preset article is to trace back the connection between architectural replanning of the city and creation of new rules of a civilized social life as well as to study response to such transformations in art, particularly, in literature. Osman's Paris was an example of total city replanning that was famous during the industrial age. Even though Osman destroyed many historical monuments and completely changed the atmosphere of Paris, today it is no doubt that he had a positive impact on the development of the city. Osman's reforms led to creation of cultural dialectics that solved the conflict between the new and the old. The initial rejection of transformations was replaced by the two tendencies: firstly, the old was valued again and the past was tried to be preserved and secondly, the new became part of everyday life, art and culture of that epoch.
\end{abstract}

Ключевые слова: Париж, барон Осман, Наполеон III, перепланировка Парижа, Шарль Бодлер, кафе-шантан, Ги де Мопассан, Эйфелева башня, Мулен Руж, массовая культура

Keywords: Paris, Baron Haussmann, Napoleon III, architectural replanning of Paris, Charles Baudelaire, café-chantant, Guy de Maupassant, the Eiffel Tower, Moulin Rouge, mass culture.

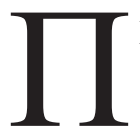

роблема перехода общества от эпохи культуры к эпохе цивилизации интересовала мыслителей, начиная с XVIII века. Традиция противопоставления цивилизации и культуры восходит к И. Кантуํㅛㄹ В работе «Метафизика нравов» (1785) он писал, что главной це-

${ }^{1}$ Кант И. Метафизика нравов. Ч. 2 // Соч. в 6 т. Т. 4, ч. 2. - М., 1965. лью культурного развития человечества является нравственное совершенствование. Культура проявляется в умении преодолевать свои эгоистические потребности, в стремлении подчиниться нравственному долгу. Культура в своей основе нравственна.

Цивилизация же, по Канту, требует от человека проявлять лишь внешнюю воспитанность, соблюдать благопристойную форму поведения, в связи 
с чем, он определяет цивилизацию как внешнее подобие культуры, не наполненное моральным содержанием. Быть цивилизованным - еще не значит быть культурным. Важнейшая задача культуры - это воспитание нравственного человека².

Тему соотношения культуры и цивилизации также рассматривает в своей работе «Закат Европы» (1918) О. Шпенглер. С помощью этих категорий Шпенглер пытается осмыслить динамику культурно-исторического процесса, выявить его закономерности. Цивилизация, по Шпенглеру, противостоит культуре: если в основе культуры лежит гуманистическое начало, то сущностью цивилизации является практицизм и прагматизм. В отличие от культуры цивилизация лишена творчества: «она ничего не создает, она только перетолковывает»³. К другим признакам цивилизации Шпенглер относил: урбанизацию, омассовление всех сфер жизни, насилие человека над природой, войны и иные конфликты. По мнению Шпенглера, «цивилизация есть неизбежная судьба культуры. Цивилизация - это самые крайние и искусственные состояния, осуществить которые способен высший вид людей» ${ }^{4}$. Шпенглер останавливается на двух примерах перехода от культуры к цивилизации: в поздней античности, в IV веке, и в Западной Европе в XIX веке. С этого момента ареной всех важных решений становится не вся страна, а три или четыре мировых города, по отношению к которым вся остальная страна культуры низвергается в положение «провинции, имеющей своим исключительным назначением питать эти мировые города остатками своего высшего человеческого материала» ${ }^{5}$. Слова философа актуальны по сей день и отражают ту историческую ситуацию, в которой мы живем. Современность есть фаза постоянно расширяющейся сферы цивилизации и постоянного сокращения области культуры.

В истории русской мысли примечательным исследованием является работа Н.А. Бердяева

\footnotetext{
${ }^{2}$ По материалам: Симкина Н.Н. Культурология : учебное пособие / Н.Н. Симкина. - Брянск : Издательство Брянского государственного технического университета, 2004. - 268 с..

${ }^{3}$ Шпенглер О. Закат Европы. Гештальт и действительность. Изд. Мысль, 1998, 663 с.

${ }^{4}$ Там же.

${ }^{5}$ Там же.
}

«О культуре» ${ }^{6}$. Цивилизацию и культуру он рассматривает как взаимоисключающие понятия. По мнению философа, культура - явление индивидуальное и неповторимое, цивилизация же - явление общее и повсюду повторяющееся.

В отличие от изложенного выше восприятия проблемы соотношения культуры и цивилизации, в данной статье эволюция от культуры к цивилизации понимается в более позитивном ключе, как необходимый переход от консерватизма к современности. Цивилизация и культура в нашем понимании являются органично связанными фазами развития. Цивилизация содержит в себе мощный потенциал научно-технического прогресса и способствует повышению качества и уровня жизни людей, более комфортному их существованию. «Цивилизация, - отмечает исследователь, - это созданный и преобразованный человеком мир внешней социальности и внеположенных ему материальных объектов, культура - внутреннее достояние самого человека, его духовная экзистенция, достигнутая степень внутренней свободы» ${ }^{7}$. Цивилизация выступает как отчужденная в институциональных, общезначимых процессах культура. Именно цивилизация вырабатывает средства, постоянно сокращающие вмешательство человека в мир природы, что является необходимым признаком культуры. Цивилизация, являясь результатом культуры, не противостоит ей. Цивилизация - это такое состояние общества, которому присущ высокий уровень тиражирования и массового распространения результатов культуры и их эффективное функционирование во всех отраслях бытия общества. В статье переход от культуры к цивилизации рассматривается на конкретном примере - на истории развития в XIX веке столицы Франции - Парижа и отражении этого процесса в литературе того времени.

Начиная с первой половины XVIII века власти Парижа задумывались о необходимости перестроить центр города: облагородить набережные Сены и снести дома, построенные на мостах.

\footnotetext{
${ }^{6}$ Бердяев Н. Философия творчества культуры и искусства. М., 1994.

7 Митрошенков О.А.. Философия: Учебник / Под ред. проф. О.А. Митрошенкова. - М. : Гардарики, 2002. $655 \mathrm{c}$.
} 


\section{Политика и общество 10 (106) • 2013}

В годы интенсивного индустриального развития Франции население Парижа росло исключительно быстрыми темпами. Город оказался не предназначен для такого большого количества жителей. Сеть узких кривых улиц, плотно застроенных зданиями, затрудняла дорожное движение, а плохие санитарные условия вызывали частые вспышки эпидемий. Это привело к тому, что богатые парижане покинули город и переселились в пригороды на север и запад, а центр столицы превратился в квартал бедняков, подверженный также и частым социальным волнениям. Для устранения подобных проблем требовалась крупная перепланировка.

Выбранный президентом Французской республики в 1848 году, Наполеон III провозгласил себя императором французов в 1852 после совершенного им государственного переворота. В планы императора входили не только улучшение транспортного сообщения, системы здравоохранения Парижа и улучшение жилищных условий низшего класса, но и повышение своего авторитета среди парижан.

Для осуществления своего замысла Наполеон III в 1853 году назначил префектом департамента Сена барона Жоржа Эжена Османа (1809-1891). Получив карт-бланш от монарха, Осман практически перекроил уличную сеть Парижа. Он разрушил его старую часть для создания основных осей, насквозь пронизывающих столицу и открывающих виды на многие выдающиеся монументы города. Все градостроительные работы имели под собой социальные и военные причины.

Именно при бароне Османе появляются признаки нового Парижа: происходит изменение социального климата, изменение внешнего вида города, изменение и внедрение новой структуры общественного бытия - массовой.

Османовский Париж явился образцом тотальной перестройки города в индустриальную эпо$\mathrm{xy,} \mathrm{в} \mathrm{эпоху} \mathrm{формирования} \mathrm{массового} \mathrm{общества.}$ После барочной перестройки Рима (проект К. Мадерны 1603-года) и послепожарного возрождения Лондона (1670-80-е гг.) это было первое полное преобразование жизненной среды в таких масштабах. Целью преобразований было создание города как единого организма, рационализация путей сообщения, снятие резких границ между центром и пригородами, включение их в городскую черту, расширение урбанизированного пространства города, а также углубление культивированности в его пределах. Впервые стал вопрос о создании новых правил иивилизованного общежития: особое внимание было уделено местам для прогулок и развлечений (Булонский лес, Венсеннский парк), открылись знаменитые кафешантаны (Фоли-Бержер, Мулен Руж) и прочие места массового досуга. Не стоит недооценивать и умиротворяющую направленность всех подобных проектов: стремление барона Османа притушить пыл воинственно настроенного населения - стремление, неотъемлемое от социальных преобразований и стратегического украшения города. Градостроительные работы барона Османа во многом определили современный облик Парижа. Перепланировка столицы включила в себя не только работы по облагораживанию ее внешнего облика, но и привела к существенному улучшению ее инфраструктуры

Миф о Париже как образе современности и воплощении нового восприятия мира импонировал даже самым консервативным кругам общества. Париж ослеплял наблюдателя в период после конца империи и при Третьей республике. Но с течением времени многие flâneurs $^{8}$ превратились в мыслителей, излагавших свои наблюдения в форме критических статей. Они признавали, что появился новый впечатляющий город; но, по их мнению, после радикальных $1848^{9}, 1851^{10}$ и $1871^{11}$ годов горожане начали отстраняться от

${ }^{8}$ От фр. - человек, гуляющий без дела, праздношатающийся.

9 Революция 1848 года во Франции- буржуазно-демократическая революция во Франции, задачами которой было установление гражданских прав и свобод. Результатом стало отречение от престола короля ЛуиФилиппа I и провозглашение Второй республики. В президенты нового государства был избран в дальнейшем ходе революции, после подавления восстания в июне 1848 , племянник Наполеона Бонапарта Луи-Наполеон Бонапарт (Наполеон III).

102 декабря 1851 года - президент Франции Луи Наполеон Бонапарт совершил переворот и распустил Законодательное собрание.

111871 ознаменовался двумя крупными событиями: это Франко-прусская война (1870-1871) - см. сноску c. 41 - и Парижская коммуна, короткий период деятельности революционного правительство Парижа, когда вскоре после заключения перемирия с Пруссией во время Франко-прусской войны в Париже начались 
жизни столицы ${ }^{12}$. Труды Османа ускорили этот процесс, так как показали парижанам, что те никак не могут противостоять разрушению собственных домов. Беспокойство и разочарование, которые принесли все перечисленные события, лирически описал Шарль Бодлер в своей поэме «Лебедь»: «Где старый мой Париж!.. Трудней забыть былое, И Чем внешность города пересоздать! Увыl!..» ${ }^{13}$. В отличие от тех, кто предпочитал наслаждаться благами Парижа, поэт избегал популярных среди путешественников бульваров, магазинов, парков и мест развлечений. Он обратился к притонам бродяг, воров-карманников, уличных актеров и морально опустившихся интеллектуалов, ютившихся в темных тупичках, на грязных улочках бедных районов и замусоренных окраинах. Поэт хорошо понимал, что обновительный проект Османа был во многом мифом - прикрытием разрушений и авторитаризма. Наблюдая за толпой, Бодлер заметил, что вкусы нового общества ему претят. Он скучал по старому Парижу, который, казалось, ушел безвозвратно: «Париж меняется - но неизменно горе; Фасады новые, помосты и леса, П Предместья cтарые - все полно аллегорийl Для духа, что мечтам о прошлом отдался» ${ }^{14}$.

В русской литературе противоречивость восприятия нового облика Парижа ярко отразилась в повести Н.В. Гоголя «Рим» (1842). Естественно, Гоголь посетил столицу Франции до глобальной перестройки Османа, но уже тогда Париж представлял собой зарождающийся город цивилизации, в сравнении с консервативным папским Римом, выступающим вечным, но обветшавшим островом культуры: «Вечное еe [заальпий-

волнения, вылившиеся в вооруженное восстание, завершившееся установлением самоуправления, длившегося 72 дня (с 18 марта по 28 мая). Во главе Парижской коммуны стояли объединённые в коалицию социалисты и анархисты; представители обоих течений считали Парижскую коммуну первым образцом диктатуры пролетариата в мировой истории.

12 Джонс К. Париж: биография великого города / Колин Джонс; [пер. с англ. Д. Ищенко]. - М.:Эксмо; СПб.: Мидгард, 2007. - 736 с.: ил. - (Биография великих городов).

13 Поэма «Лебедь» Ш. Бодлера (1821-1867), сборник «Цветы зла», 1867.

14 Там же. ской Европы, в представлении молодого князя, ее олицетворяет Париж] движение и блеск заманчиво мелькали вдали. Там была новость, противоположность ветхости итальянской, там начиналось ХІХ столетие, европейская жизнь» ${ }^{15}$. Гоголь противопоставляет якобы остановившуюся жизнь Вечного города стремительным изменениям враждебного человеку капиталистического «прогресса», с которым писатель столкнулся в Западной Европе и который навсегда отвратил его от уже не революционного, а буржуазного Парижа ${ }^{16}$ : «Вот он, Париж, это вечное, волнующееся жерло, водомет, мечущчий искры новостей, просвещуенья, мод, изысканного вкуса и мелких, но сильных законов, от которых не властны оторваться и сами порицатели их, великая выставка всего, что производит мастерство, художество и всякий талант, скрытый в невидных углах Европы, трепет и любимая мечта двадцатилетнего человека, размен и ярмарка Eвponы!». Бурление западноевропейской столицы на поверку оказалось бессодержательной суетой, засасывающей и съедающей живого человека. Даже светские львы обернулись «парижскими крокодилами». В гоголевском отрывке наметились некоторые бальзаковские темы, в частности столь важная для почти всей западноевропейской литературы XIX века тема утраты иллюзий ${ }^{17}$. «Bo многом он разочаровался,- говорит Гоголь об итальянском князе.- Тот же Париж, вечно влекущиий к себе иностранцев... уже показался ему много, много не тем, чем был прежде» ${ }^{18}$. Особо он отмечает поверхностность кажущейся роскоши и величия, показывая изнанку стремительной жизни Парижа: «B движении торговли, ума, везде, во всем видел он только напряженное усилие и стремление к новости. Один силился пред другим, во что бы то ни стало, взять верх, хотя бы на одну минуту. Купец весь капитал свой употреблял на одну только уборку магазина, чтобы блеском и великолепием его заманить к себе тол-

\footnotetext{
15 Гоголь Н.В. Рим (Отрывок). Собрание художественных произведений в пяти томах. Том 3. М., Издательство Академии наук СССР, 1952.

${ }^{16}$ Хлодовский Р. Рим в мире Гоголя\\Иностранная литература, 1984, №12, сс. 203 - 210 .

17 Там же.

${ }^{18}$ Там же.
} 


\section{Политика и общество 10 (106) 2013}

nу. Книжная литература прибегала к картинкам и типографической роскоши, чтоб ими привлечь $\kappa$ себе охлаждающееся внимание. <..> В самой науке <..> стало ему заметно везде <..> усилия поднять доселе незамеченные факты и дать им огромное влияние иногда в ущерб гармонии ичелого, с тем только, чтобы оставить за собой честь открытия» ${ }^{19}$.

Тем не менее, внедрение новых технологий, новых способов коммуникации, появление новых архитектурных решений вызывает широкий резонанс: общество делится на новаторов, тех, кто поддерживает изменения, и традиционалистов, которые отвергают нововведения.

Парадно-представительный османовский город превращал людей в ничтожную частицу безликого множества, делал их винтиками городского механизма, каждое их действие было подконтрольно властям. Средний парижанин, утверждал Максим Дюкан, стал пассивным, загнанным в административную скорлупу, «вписанным в реестр, внесенным в каталог, пронумерованным, помещенным под наблюдение, освещуенным, почищенным, ведомым, опекаемым, предупрежденным, арестованным, судимым, посаженным в тюрьму и похороненнымм» ${ }^{20}$. Это мнение разочарованного показывает, что имя Османа и модернизм стали повинны во всех грехах изменяющегося общества и новой исторической эпохи - индустриальной цивилизации.

С вершины Эйфелевой башни, открытой для поклонников прогресса во время выставки 1889 года, всякий мог узреть во всей красоте сердце города Османа. Взгляду открывались не только роскошные бульвары и шикарные магазины западной стороны города, но фабрики и рабочие кварталы окраинных округов. Город разворачивался перед глазами одновременно как центр потребительской культуры и как промышленный и ремесленный. Осману не удалось полностью укротить даже центр столицы, хотя барон занимался им особенно

\footnotetext{
${ }^{19}$ Гоголь Н.В.. Рим (Отрывок). Собрание художественных произведений в пяти томах. Том 3. М., Издательство Академии наук СССР, 1952.

20 Дюкан М. Париж, его органы, отправления и жизнь во второй половине XIX века. 2 тома. Издание редакции журнала «Всемирный путешественник». Спб., типография товарищества «Общественная польза», 1875 .
}

плотно. Несмотря на то, что le Vieux Paris - «старый Париж» - расчленили и превратили в небольшие управляемые островки, он продолжал жить всего в нескольких метрах от улицы де Риволи и бульвара Сен-Мишель.

Особое внимание перестройке Парижа уделил в своем творчестве Эмиль Золя. При написании романа «Добыча» (1871) он занимает позицию стороннего наблюдателя и как историк изучает многочисленные материалы, которые достоверно характеризуют общественные нравы периода правления императора Наполеона III. Устами главного героя романа Аристида Ругона (под именем Саккара) он излагает план перестройки столицы: «Посмотри в ту сторону, где рынок, Париж разрезали на четыре части. И протянутой рукой, держа ладонь ребром, как нож, Саккар словно разрезал город на четыре части.

- Ты говоришь об улице Риволи и новом бульваре, который сейчас прокладывают?

- Да, они называют это больиим окном Парижа; они хотят высвободить Лувр и ратушу. Детская игра, способная лишь разжечь страсти... Как только проведут первую сеть улиц, тут-то и начнется. Вторая сеть перережет город по всем направлениям, соединит с первой предместья; все, что останется от старого, умрет, задохнется в пыли известки... Последи за моей рукой, смотри сюда. От Тампльского бульвара до Тронной заставы - первый прорез; другой будет с этой стороны, от иеркви Магдалины до равнины Монсо; третий - в этом направлении, четвертый-в том. Тут прорез, там прорез, всюду прорезы. Весь Париж искромсают сабельными ударами, вены его вскроют, он накормит сто тысяч землекопов и каменщиков, его пересекут великолепные стратегические пути с укреплениями в самом сердие старых кварталов.

$<\ldots>-$ Будет проложена еще и третья сеть, - продолжал, помолчав, Саккар, как бы разговаривая сам с собой, - но не скоро, я ещче плохо вижу ее, у меня мало указаний... И это уже будет настоящим безумием, адским галопом миллионов. Париж напоят допьяна и пристукнут» ${ }^{21}$.

\footnotetext{
21 Золя Э. Добыча. Перевод с французского Т. Ириновой.\ Ругон-Маккары. Эмиль Золя. Собрание сочинений в 18 томах. Том 1. М., «Правда», 1957. Под редакцией А. Пузикова.
} 
Вторая империя весьма благоприятствовала обогащению банковской олигархии, крупной промышленной и торговой буржуазии. Несмотря на все видимые плюсы, осуществление османовского плана реконструкции способствовало огромному размаху спекуляций недвижимостью. В этом же романе Золя показал, как обогатились в результате этих спекуляций дельцы, которые за бесценок скупали старые дома и добивались затем их реквизиции государством, что позволяло им перепродавать их по цене в 20 или 30 раз более высокой, чем та сумма, которую они заплатили за них. Писатель хотел увековечить «звон золота, шуршание миллионов, шумные оргии плоти», «вакханалию дебошей», характеризовавшие эту эпоху 22 . В своем произведении Эмиль Золя начинает подведение первых итогов существования Второй империи в те времена, когда власть Наполеона III была еще достаточно крепка. Его герой Аристид Ругон является олицетворением дельцов, которые движимы всепоглощающей целью - сколотить состояние, присвоить часть от общей добычи; планы перестройки Парижа открывали широкий простор для их финансовых махинаций.

«Механизм отчуждения в интересах города, этой мощной машинь, которая пятнадцать лет перемальвала Париж, неся с собой то богатство, то разорение, был чрезвычайно прост. Как только выходило постановление проложить новую улииу, межевые агенты составляли план и оценивали владение. Когда дело касалось дома, они, после обследования, капитализировали обычно доход домовладельца в изелом от сдачи внаем квартир и торговых помещений и, основываясь на этих выкладках, определяли приблизительную стоимость дома. Комиссия по возмещению убытков, состоявщая из членов муниципального совета, предлагала всегда более низкую цену, зная, что заинтересованные лица потребуют больше, и тогда обе стороны шли на взаимные уступки.

Когда стороны не могли договориться, вопрос о сумме, предлагаемой городом и требуемой домовладельцем или выселяемым жильцом,

22 Пузиков А. Предисловие к собранию сочинений Эмиля Золя в 18 томах. Том 1. М., «Правда», 1957. Под редакцией А. Пузикова. передавался на рассмотрение жюри, и его решение являлось окончательным» ${ }^{23}$.

Саккар, как и многие дельцы того времени, извлекает свою выгоду из перестройки Парижа, он использует различные комбинации, скупая предназначенные для слома ветхие дома, и с помощью хитрости и обмана становится одним из богатейших людей империи. Саккар является собирательным образом, в котором воплощены черты многих сподвижников Наполеона III. Других персонажей Золя также наделяет типичными чертами героев своего времени. Здесь и барон Гуро, получивший баронский титул еще от Наполеона I и ставший пэром Франции при Людовике XVIII, Карле X и Луи-Филиппе; и Тутен-Ларош, «ограниченный ум, пособный только на темные коммерческие махинации» ${ }^{24}$; и чиновник Мишлен, сумевший с помощью жены продвинуться по служебной лестнице; и мошенник Ларсоно, «способный своим преследованием довести должника, подписавшего вексель, до самоубийства» ${ }^{25}$; и госпожа Лоуренс, которая занимает высокое положение в обществе, но при этом не брезгует наживаться на сводничестве. Такова опора империи, «как величайшую национальную трагедию изображает Золя торжество всего этого сброда, расточающего народное богатство, утопающего в бессмысленной роскоши. Будущий министр при Наполеоне III, брат Саккара, Эжен Ругон, так формулирует причины, побуждающие правительство опираться на людей, безудержно рвущихся к богатству и наслаждениям» ${ }^{26}:$ «У нас всегда будет накрыт стол, и мы сумеем удовлетворить самые большие аппетиты. Это наиудобнейший метод для того, чтобы изарить...» ${ }^{27}$.

Однако Золя подчеркивал не только негативную сторону процесса, но отмечал и позитивную:

23 Золя Э. Добыча. Перевод с французского Т. Ириновой.\ Ругон-Маккары. Эмиль Золя. Собрание сочинений в 18 томах. Том 1. М., «Правда», 1957. Под редакцией А. Пузикова.

24 Там же.

${ }^{25}$ Там же.

${ }^{26}$ Пузиков А. Предисловие к собранию сочинений Эмиля Золя в 18 томах. Том 1. М., «Правда», 1957. Под редакцией А. Пузикова.

27 Золя Э. Добыча. Перевод с французского Т. Ириновой. \ Ругон-Маккары. Эмиль Золя. Собрание сочинений в 18 томах. Том 1. М., «Правда», 1957. Под редакцией А. Пузикова. 


\section{Политика и общество 10 (106) • 2013}

«Парижские работы, - сказал он, - дали заработок рабочему человеку.

- Можно ещче добавить, - продолжал г-н Тутен-Ларош, - что они дали мощуный толчок финансам и промышленности.

- Не забудьте также художественную сторону дела: новые улицы полны величия, - добавил г-н Юпель де ла Ну, который чванился своим вкусом.

- Да, да, прекрасная работа» ${ }^{28}$.

Ранее уже говорилось о том, какое внимание Осман уделял строительству новых парков и реставрации существующих. Насаждения, призванные стать легкими города, были навязчивой идеей для императора. Золя позитивно оценивает этот проект префекта: «Им нравился этот прелестный уголок нового Парижа, приветливая, чистенькая природа, лужайки, окаймленные роскошными бельми розами, раскинувшиеся точно куски бархата с разбросанными на них изветочными клумбами и отборными кустарниками $<\ldots>$ Между деревьями сверкала позолоченная решетка, стая уток пльла по озеру, среди зелени белел новенький мостик в стиле ренессанс» ${ }^{29}$.

Большое внимание Золя уделяет интимно-бытовой теме, связывает ее с социальной темой и расширяет ее. Вторая империя породила не только мошенников и махинаторов, но и расслабленных обывателей, которые эгоистично думали лишь об удовлетворении своих прихотей, в романе это молодая супруга Саккара и его сын Максим. Их образы свидетельствовали о внутреннем разложении Второй империи ${ }^{30}$ :

«Максим и Рене полюбили новый Париж. < .. > Их восхищали высокие дома с резными дверьми в иироких подъездах, со множеством балконов, где сверкали огромные золотые буквы имен, вывесок, названий фирм. Коляска быстро катила, они дружелюбно оглядывали серую полосу широких, бесконечно длинных тротуаров, со скамей-

28 Золя Э. Добыча. Перевод с французского Т. Ириновой. \ Ругон-Маккары. Эмиль Золя. Собрание сочинений в 18 томах. Том 1. М., «Правда», 1957. Под редакцией А. Пузикова.

${ }^{29}$ Там же.

${ }^{30}$ Пузиков А. Предисловие к собранию сочинений Эмиля Золя в 18 томах. Том 1. М., «Правда», 1957. Под редакцией А. Пузикова. ками, пестрыми колоннами и чахлыми деревьями. Просвет бульвара, уходивший, постепенно суживаясь, в голубое пространство на горизонте, непрерывный двойной ряд больших магазинов, где приказчики ульбались покупательницам, быстрое движение шумливой толпь - все это давало им полное удовлетворение, ощущение совершенства уличной жизни. <..> Им казалось, что экипаж их катится по ковру вдоль прямого нескончаемого проспекта, который провели исключительно для того, чтобы избавить их om темных переулков» ${ }^{31}$. Максим и Рене молоды, они мягче воспринимают действительность, открыты к изменениям, не жалеют об ушедшем. В романе они занимают позицию нового поколения, уже принявшего новый образ жизни.

Подтверждение того, что город изменился до неузнаваемости, не раз встречается в тексте романа, от разных героев можно услышать: «- Bbl совершили чудеса, - сказал Саккар, - Париж стал мировой столицей.

- Да, правда, это изумительно, - перебил Юпель де ла Ну. - Представьте себе, я, старый парижанин, не узнаю Парижа. Вчера я заблудился по дороге из ратуши к Люксембургскому двориу. Изумительно, изумительно!» или «Он внимательно осматривал окружавщие его развалины и не узнавал квартала, где, по его словам, жил лет тридцать тому назад, как только приехал в Париж» ${ }^{32}$.

С укреплением репутации столицы Франции как города современности, росла и ностальгия по le Vieux Paris - старому Парижу - грязному, но настоящему, более человечному. Золя обличает «власть имущих» и со страстью клеймит позором всех тех, кто нажился нечестным путем, в его романе проскальзывает тоска по ушедшему Парижу: «Ему доставило бы удовольствие снова увидеть старые места. Он поворачивался, оглядывался по сторонам и вдруг остановился, как вкопанный, посреди дороги перед домом, уже рассеченным пополам кирками».

31 Золя Э. Добыча. Перевод с французского Т. Ириновой.\ Ругон-Маккары. Эмиль Золя. Собрание сочинений в 18 томах. Том 1. М., «Правда», 1957. Под редакцией А. Пузикова.

32 Золя Э. Добыча. Перевод с французского Т. Ириновой.\ Ругон-Маккары. Эмиль Золя. Собрание сочинений в 18 томах. Том 1. М., «Правда», 1957. Под редакцией А. Пузикова. 
Помимо материального улучшения жизни столицы, изменилась повседневная жизнь горожан, все больше времени люди теперь проводили в местах массового посещения - магазинах, кафе.

Магазины, похожие на современные торговые центры ${ }^{33}$, предоставили потребителю новый способ совершать покупки, оставив пассажи времен Реставрации и Июльской монархии в прошлом. Теперь в зданиях из стекла и металла, в интерьерах, навевавших воспоминания о восточных сказках, продавались последние достижения технического прогресса. У населения появились привычки разглядывать витрины, прогуливаться между прилавков, общаясь с другими покупателями и совершая спонтанные покупки. Эти храмы потребительского спроса богатыми интерьерами и низкими ценами влекли с бульваров все классы общества: «от графини до кокотки, от миллионера до попрошайки» ${ }^{34}$. Магазины занимались тем же, чем и многие писатели: играли на фантазиях потребителя. Описание магазина в романе Эмиля Золя «Дамское счастье» (1883 г.), например, явно изображает «Bon Marché». Автор мастерски сыграл на желаниях и фантазиях своих читателей (и парижских потребителей), через пару лет витрины «Bon Marché» были оформлены именно так, как описано в романе:

${ }^{33}$ Идея создания большого торгового центра принадлежит Аристиду Бусико. В 1852 году он становится совладельцем галантерейного магазина, называемого «Bon Marché» на Рю де Севр. «Bon Marché» быстро развивается: из 4 отделов с 12 работниками вырастает на тот момент самый большой в мире торговый центр с 1788 служащих. Идея концепции универмага приходит Бусико во время всемирной выставки 1855 года. Стремясь возобновить то изобилие товаров, какое поражало воображение на выставке, он изобретает концепцию свободного доступа потребителя к товару без обязательной покупки, фиксирует цену, вешая на товар этикетки, что избавляет покупателей от привычки торговаться, расширяет ассортимент и количество отделов, чтобы потенциальный покупатель больше прогуливался по универмагу, рассматривая товар и совершая импульсивные покупки. Бусико проводит политику меньшей цены, компенсируя ее большим товарооборотом. Тогда же в практику входит обмен или возврат неудовлетворительного товара.

34 Дюкан М. Париж, его органы, отправления и жизнь во второй половине XIX века. 2 тома. Издание редакции журнала «Всемирный путешественник». Спб., типография товарищества «Общественная польза», 1875 .
«Но Дениза вся ушла в созерияание выставки товаров, расположившейся у иентрального входа. Здесь, под открытым небом, у подъезда, были разложены, точно приманка, груды дешевых товаров на все вкусы, чтобы прохожие могли их купить, не заходя в магазин. Сверху, со второго этажа, свешивались, развеваясь как знамена, полотнища шерстяной материи и сукон, материи из мериносовой шерсти, шевиот, мольтон; на их темно-сером, синем, темно-зеленом фоне отчетливо выделялись белье ярльчки. <..> Денизе бросилась в глаза клетчатая материя по сорок пять сантимов за метр, икурки американской норки по франку за штуку, митенки за пять cy. Это было похоже на гигантскую ярмарку; казалось, магазин лопнул от множества товаров $и$ избыток их вылился на улицу...». Как и Дениза, покупатели могли переходить от витрины к витрине, «подолгу простаивая перед каждой». Подобно героям Золя их поражало «замысловатое устройство выставок: вверху по диагонали были расположены зонтики в виде крыши деревенской хижины; внизу на металлических прутьях висели шелковые чулки, словно обтягивавшие округлье икры ; <..>. Наконец, на полках, покрытых сукном, лежали симметрично разложенные перчатки с удлиненными, как у византийской девственницьы, пальцами и с ладонью, отмеченной какою-то чуть угловатой, поистине девичьей грацией, как все ещче не ношенные женские наряды. < ..> А по обеим сторонам витрины высились груды шелка двух сортов: "Счастье Парижа» u «Золотистая кожа»: шелка эти продавались только здесь и были из ряда вон выдающимся товаром, которому предстояло произвести переворот в торговле новинками» ${ }^{35}$. Огромные объемы продаж вынуждали хранить большие запасы на складах и дали импульс парижскому производству, традиционно специализировавшемуся на изготовлении товаров для богатых покупателей и людей со средним достатком. Так, производственный сектор старых и новых округов были вовлечены в бесконечный цикл продаж grands magasins.

35 Эмиль Золя. Дамское счастье. Перевод с французского Т. Ириновой. $\$ Эмиль Золя. Собрание сочинений в 18 томах. Том 9. М., «Правда», 1957. Под редакцией А. Пузикова. 


\section{Политика и общество 10 (106) 2013}

Золя остро реагировал на изменения, происходящие в жизни общества, и ненавидел зло, порождаемое буржуазными отношениями.

Интересный отклик деятельность Османа получила в произведении Виктора Гюго «Париж» (1867). Можно сказать, что он публикует его в качестве некоего манифеста. Автор философски подходит к изменениям в городе и задает больше вопросов, чем дает ответов, заставляя читателя самого вдуматься в происходящее, проанализировать ситуацию в контексте современной ему истории: «Но, скажут нам, а новейчий Париж, Париж последних пятнадиати лет, этот ночной гул, эти маскарады и вакханалии, Париж, говоря о котором часто применяют слово “упадок”,- что вы думаете о нем? - Что мы о нем думаем? Mbl не верим, что он существует. Да и есть ли такой Париж вообще? А если он и есть, то относится к истинному Парижу, Парижу прошлого и будущего, как лист к дереву. И даже меньше того. Как опухоль к организму. Разве вы станете судить о дубе по растущей на нем омеле?» ${ }^{36}$. В рядах интеллигенции мало позитивных оценок и мнений о перестройке столицы: на первый план выходит третье сословие, развлечения становятся доступными не только для высшего света, но и для простых горожан, социальные границы стираются, это не могло понравиться аристократии: «Порочить Париж, хулить его, высмеивать, презирать - не так уж трудно. Ничего нет проше, как свысока говорить о колоссах. В этом даже есть что-то детское. Для такой изели существуют готовые фразы»» ${ }^{37}$. Гюго можно назвать представителем широкой демократии, он призывает быть прогрессивными, открыться навстречу будущему, принять новый Париж как ступень к свободе. Гюго был уверен, что установление республики разрешит все социальные вопросы буржуазного общества, обеспечит свободу, равенство и братство, за которые боролись еще великие просветители XVIII века, и сделает счастливыми всех людей: «Быть Парижем - значит двигаться вперед. Сегодня, когда реакиия ополчается против всего прогрессивного, обличаемого и властью папских посланий, и божественным

\footnotetext{
${ }^{36}$ Гюго В. Париж. Собрание сочинений в 15 томах. Том 14. - М.: Государственное издательство художественной литературы, 1956.

37 Там же.
}

правом, и “хорошим вкусом”, и сакраментальным magister dixit, и рутиной, и традицичеи, и т. д.; когда все прошлое - фанатизм, схоластика, неоспоримыл авторитеть - открыто восстает против могучего девятнадияатого века, сына революичи и отияа свободы,--именно сегодня полезно, необходимо, справедливо воздать должное Парижу. Признать Париж-значит подтвердить, вопреки всем очевидностям, принимаемым на веру чернью, что всеобщее движение к свободе неудержимо продолжается. Сейчас вся темная клика старых предрассудков и старых режимов торжествует победу и считает, что Париж в беде, подобно тому как дикари во время затмения думают, что солнце в опасности» ${ }^{38}$. «Париж» Гюго олицетворяет историческую ситуацию. Роман написан в 1867 году, во времена, предшествующие Парижской коммуне. На назревающий революционный кризис возлагалась надежда открыть новые горизонты и проложить новые пути, по которым пойдет демократическое движение, поднимаясь еще выше в своей великой борьбе за свободу Человека. Автор осознает давление реакции, но им принимается основная линия, направленная вперед, к прогрессу.

Тему изменившегося города затрагивает в своих произведениях Ги де Мопассан. Но его, в отличие от Золя, больше интересует не сама фактическая перестройка Парижа, не изнанка становления столицы мира, не финансовые махинации дельцов, но приспособление парижан к новой жизни, их стремление трудом или хитростью забраться на верх карьерной лестницы, а также изменение уклада жизни горожан, их привычек, характера и восприятия окружающего мира. Особое внимание он уделяет деталям, по мнению некоторых историков, его прозу можно с полным правом назвать «документальной»: Париж Мопассана, его улицы и дома, театры, ночные кафе-варьете и населяющие его буржуа и аристократы, чиновники и «низы» общества наделены очень ясным колоритом времени ${ }^{39}$.

\footnotetext{
${ }^{38}$ Гюго В. Париж. Собрание сочинений в 15 томах. Том 14. - М.: Государственное издательство художественной литературы, 1956.

${ }^{39}$ Потапова 3. М. Ги де Мопассан // История всемирной литературы: В 8 томах / АН СССР; Ин-т мировой лит. им. А. М. Горького. - М.: Наука, 1983-1994. - На титл. л. изд.: История всемирной литературы: в 9 т. Т. 7. 1991. - С. 299-308.
} 
По мере того как герой романа «Милый друг», Жорж Дюруа, пробивает себе «путь наверх», раскрываются различные сферы нравственной, идеологической, политической жизни буржуазной Франции. И повсюду - в сфере интимной и сфере общественной - автор констатирует цинизм и беспринципность, коррупцию и своекорыстие, распад идейных и моральных ценностей: «Появились две женщины с рапирами в руках, в фехтовальных костюмах <..> Зрители были в восторге от этих двух вочтельниц: мужчины - оттого, что они разжигали их чувственность, женщины - оттого, что они будили в них врожденную страсть парижан к нескромным увеселениям, к развлечениям низкого пошиба, к поддельной красоте и поддельному изяшеству, к опереточным куплетам и кафешантанным певичкам» ${ }^{40}$. В этом романе Мопассан использует опыт Золя, перенеся героя в ту область общественно-культурной деятельности, которую Золя в своем романном цикле не затронул, - в журналистику. В «Милом друге» показано, как бульварная газета становится влиятельной общественной силой, как сращивается пресса с банковскими спекуляциями и колониальной политикой, как владельцы прессы становятся «меценатами искусства», как, пользуясь бессовестностью мошенника-журналиста, можно свергнуть министра. Мопассан настаивает прежде всего на безнравственности карьеры Жоржа Дюруа, который взбирается по служебной лестнице, добивается богатства, ордена, положения в свете и, наконец, блестящей женитьбы одним и тем же нехитрым способом - соблазняя женщин, ум, красоту и влияние которых он использует, а затем обворовывает, обманывает, позорит, бросает их ${ }^{41}$. Всеобщая продажность и развращенность наполняют атмосферу, в которой живут герои романа. Продаются газеты, депутатские голоса, сведения и убеждения, таланты и способности, стихи и проза. В этой атмосфере и «оперяется» Жорж Дюруа для своего полета

40 Ги де Mопассан. Милый друг. Полное собрание сочинений в 12 томах. Т. 5. М.: Правда, 1958. - Библиотека «Огонек». - с. 493.

${ }^{41}$ Потапова 3. М. Ги де Мопассан // История всемирной литературы: В 8 томах / АН СССР; Ин-т мировой лит. им. А. М. Горького. - М.: Наука, 1983-1994. - На титл. л. изд.: История всемирной литературы: в 9 т. Т. 7. 1991. - C. 299-308. к вершинам успеха. Читатель встречается с ним, когда этот сын деревенского трактирщика, бывший вахмистр колониальных войск служит мелким чиновником, получает грошовое жалованье. Вот он идет по вечернему Парижу, с завистью и ненавистью глядя на богатых господ, сидящих за столиками бесчисленных кафе, а он не может себе позволить лишнюю кружку пива. «Попадись бывиему унтер-офицеру кто-нибудь из них ночью в темном переулке,- честное слово, он без зазрения совести свернул бы ему шею...» ${ }^{42}$.

Но полагает так Жорж Дюруа лишь по неопытности и провинциальной наивности. Скоро он убедится в том, что в Париже полное раздолье для грабежа, только нужно знать, как за это взяться. Впервые город предстает как объект завоевания, как поле битвы за себя и за свою карьеру. Мелкая и грязная газетка «Французская жизнь», куда его устраивает бывший однополчанин, становится для него первой школой поведения в парижских джунглях, работа в газете приобщает его к миру политики, финансов, кулис, света и полусвета, знакомит с изнанкой парижской жизни, с кухней всех политических и деловых махинаций.

Помимо деловых махинаций, Мопассан затрагивает и тему дорожного транспорта, несмотря на существенные изменения, совершенные бароном Османом, дорожное сообщение в Париже остается далеким от идеала: «Мужчины говорили теперь все вместе, размахивая руками и часто повышая голос: обсуждался грандиозный проект подземной железной дороги (Речь идет о метро!). Тема была исчерпана лишь к кониу десерта, - каждому нашлось, что сказать о медленности способов сообщения в Париже, о неудобствах конок, о непорядках в омнибусах и грубости извозчиков» ${ }^{43}$. Можно сделать вывод о том, что споры о перестройке Парижа велись не только в административных кругах, но и в совершенно разных слоях населения, как на официальных приемах, так и в дружеских беседах.

\footnotetext{
${ }^{42}$ Ги де Мопассан. Милый друг. Полное собрание сочинений в 12 томах. Т. 5. М.: Правда, 1958. - Библиотека «Огонек». - с. 493.

${ }^{43}$ Ги де Мопассан. Милый друг. Полное собрание сочинений в 12 томах. Т. 5. М.: Правда, 1958. - Библиотека «Огонек». - с. 496.
} 


\section{Политика и общество 10 (106) 2013}

Мопассан вкладывает в уста главного героя описание времяпрепровождения парижан, хотя и весьма скептическое: «Уверяют, будто в Париже фланер всегда найдет, чем себя занять, но это не так. Иной раз вечером и рад бы куда-нибудь пойти, да не знаешь куда. В Булонском лесу приятно кататься с женщиной, а женщчины не всегда под рукой. Кафешантаны способны развлечь моего аптекаря и его супругу, но не меня. Что же остается? Ничего. В Париже надо бы устроить летний сад, вроде парка Монсо, который был бы открыт всю ночь и где можно было бы выпить под деревьями чего-нибудь прохладительного и послушать хорошую музыку. Это должно быть не увеселительное место, а просто место для гулянья» ${ }^{44}$. Это еще раз показывает, что люди были не безучастны к происходящим переменам. Это будоражило их умы, и они мечтали об изменениях, согласно их образу жизни.

Этой темы Мопассан касается и в рассказе «Мадемуазель Перль»: «Весь Париж, расположенный по ту сторону Сены, - это для Шанталей новые кварталь, причем кварталь, заселенные странными, иумными и весьма непочтенными людьми, которые день тратят на развлечения. А ночь - на кутежи и бросают деньги на ветер ${ }^{45}$. Автор дает оценку происходящего со стороны аристократов, которые не понимают безумства тех, кто еще вчера был беден, а теперь мог позволить себе тратить деньги впустую.

Без произведений талантливых литераторов нам было бы трудно оценить эпоху преобразований, происходивших в Париже в полной мере.

О Париже спорили, ему искали толкования. Диспуты о предназначении города стали неотъемлемой чертой времени - в дебатах участвовал весь мир. Несогласие в вопросах о настоящем и прошлом перетекало в споры о будущем. На рубеже веков будущее города казалось определенным. Парижане вступили в период сытости и развлечений. Поколение, выросшее после Первой мировой войны, называло то время belle époque ${ }^{46}$. Однако многие замечали и «темную

${ }^{44}$ Там же.

45 Ги де Мопассан. Мадемуазель Перль. Полное собрание сочинений в 12 томах. Т. 6. М.: Правда, 1958. - Библиотека «Огонек». - с. 448.

${ }^{46}$ От фр. - «прекрасная эпоха». сторону» перемен тех лет. Возникал даже страх апокалипсического исхода: будущее сулило гибель, а не новое начало. Период belle époque стал одновременно и fin de siècle $e^{47}$. Однако насчет одного фактора у обеих сторон мнение было однозначным: Париж больше никогда не будет таким, каким был до перестройки, атмосфера старого города ушла безвозвратно. Консерваторы, ностальгирующие по былым временам, и новаторы, с надеждой смотрящие в будущее, констатировали изменение социальной природы общества, а не только фактической перестройки внешнего облика Парижа.

Несмотря на ту разрушительную силу, которую нес с собой Осман, несмотря на уничтожение им исторических памятников и изменение атмосферы, царившей в Париже того времени, и столь ценимой современниками, его позитивное влияние на развитие города неоспоримо. Появляются не только новые типы общественных сооружений, но и новые способы коммуникации и транспортного сообщения - трамваи и метро. Город входит в новую индустриальную стадию развития массового общества. Человек как самостоятельная единица теряет свое значение, на первый план выходит толпа. Архитектурный облик подтверждает этот тезис: человеку свободно, но в то же время слишком одиноко на широких бульварах и авеню.

В ходе исследования отклика на реформы Османа в искусстве открылась диалектика культурного движения, которая разрешила конфликт между старым и новым. Первое неприятие произведенных изменений сменяется двумя тенденциями: во-первых, с новой силой открывается ценность старого, ставится проблема сохранения своего прошлого, возобновляется интерес к истории, во-вторых, новое становится повседневностью, входит в интимный мир человека, поэтизируется и включается в культурный контекст эпохи.

Яркие обновительные тенденции открыли ценность старого, в результате чего образовался синтез старого и нового как общего будущего европейской культуры, в котором мы живем по сей день.

${ }^{47}$ От фр. - «конец века». 


\section{Библиография:}

1. Бердяев Н. Философия творчества культуры и искусства. М., 1994.

2. Бодлер Ш., сборник «Цветы зла», 1867.

3. Большая советская энциклопедия. Гл. ред. А.М. Прохоров, 3-е изд. Т.10. - М.: Советская энциклопедия. 1969-1978.

4. Ги де Мопассан. Мадемуазель Перль. Полное собрание сочинений в 12 томах. Т. 6. М.: Правда, 1958.-Библиотека «Огонек».

5. Ги де Мопассан. Милый друг. Полное собрание сочинений в 12 томах. Т. 5. М.: Правда, 1958.-Библиотека «Огонек».

6. Ги де Мопассан. Подруга Поля из сборника «Заведение Телье». Полное собрание сочинений в 12 тт. Том 1. Библиотека «Огонек», Изд. «Правда», М.: 1958.

7. Гоголь Н.В.. Рим (Отрывок). Собрание художественных произведений в пяти томах. Том 3. М., Издательство Академии наук СССР, 1952.

8. Гюго В. Париж. Собрание сочинений в 15 томах. Том 14.- М.: Государственное издательство художественной литературы, 1956.

9. Джонс К. Париж: биография великого города / Колин Джонс; [пер. с англ. Д. Ищенко]. М.:Эксмо; СПб.: Мидгард, 2007. - 736 с.: ил. - (Биография великих городов).

10. Дюкан М. Париж, его органы, отправления и жизнь во второй половине XIX века. 2 тома. Издание редакции журнала «Всемирный путешественник». Спб., типография товарищества «Общественная польза», 1875.

11. Золя Э. Дамское счастье. Перевод с французского Т. Ириновой.। Эмиль Золя. Собрание сочинений в 18 томах. Том 9. М., «Правда», 1957. Под редакцией А. Пузикова.

12. Золя Э. Добыча. Перевод с французского Т. Ириновой.। Ругон-Маккары. Эмиль Золя. Собрание сочинений в 18 томах. Том 1. М., «Правда», 1957. Под редакцией А. Пузикова.

13. Кант И. Метафизика нравов. Ч. 2 // Соч. в 6 т. Т. 4, ч. 2.-М., 1965.

14. Митрошенков О.А. Философия: Учебник / Под ред. проф. О.А. Митрошенкова.-М. : Гардарики, 2002. - 655 с.

15. Потапова 3. М. Ги де Мопассан // История всемирной литературы: В 8 томах / АН
СССР; Ин-т мировой лит. им. А. М. Горького. - М.: Наука, 1983-1994. - На титл. л. изд.: История всемирной литературы: в 9 т. Т. 7.1991. - С. 299-308.

16. Симкина Н.Н. Культурология : учебное пособие / Н.Н. Симкина. - Брянск: Издательство Брянского государственного технического университета, 2004. - 268 с..

17. Хлодовский Р. Рим в мире Гоголя $\backslash$ Иностранная литература, 1984, №12, сс. $203-210$.

18. Шпенглер О. Закат Европы. Гештальт и действительность. Изд. Мысль, 1998, 663 с.

\section{References (transliteration):}

1. Berdyaev N. Filosofiya tvorchestva kul'tury i iskusstva. M., 1994.

2. Bodler Sh., sbornik «Tsvety zla», 1867.

3. Gi de Mopassan. Mademuazel' Perl'. Polnoe sobranie sochinenii $\mathrm{v} 12$ tomakh. T. 6. M.: Pravda, 1958.-Biblioteka «Ogonek».

4. Gi de Mopassan. Milyi drug. Polnoe sobranie sochinenii v 12 tomakh. T. 5. M.: Pravda, 1958.-Biblioteka «Ogonek».

5. Gi de Mopassan. Podruga Polya iz sbornika «Zavedenie Tel'e». Polnoe sobranie sochinenii v 12 tt. Tom 1. Biblioteka "Ogonek", Izd. "Pravda", M.: 1958.

6. Gogol' N.V.. Rim (Otryvok). Sobranie khudozhestvennykh proizvedenii $\mathrm{v}$ pyati tomakh. Tom M., Izdatel'stvo Akademii nauk SSSR, 1952.

7. Gyugo V. Parizh. Sobranie sochinenii v 15 tomakh. Tom 14.- M.: Gosudarstvennoe izdatel'stvo khudozhestvennoi literatury, 1956.

8. Dzhons K. Parizh: biografiya velikogo goroda / Kolin Dzhons; [per. s angl. D. Ishchenko]. M.:Eksmo; SPb.: Midgard, 2007. - 736 s.: il. (Biografiya velikikh gorodov).

9. Dyukan M. Parizh, ego organy, otpravleniya i zhizn' vo vtoroi polovine XIX veka. 2 toma. Izdanie redaktsii zhurnala «Vsemirnyi puteshestvennik». Spb., tipografiya tovarishchestva «Obshchestvennaya pol'za», 1875.

10. Zolya E. Damskoe schast'e. Perevod s frantsuzskogo T. Irinovoi.\ Emil' Zolya. Sobranie sochinenii v 18 tomakh. Tom 9. M., "Pravda", 1957. Pod redaktsiei A. Puzikova. 
DOI: $10.7256 / 1812-8696.2013 .10 .9879$

При цитировании этой статьи сноска на dоі обязательна

\section{Политика и общество 10 (106) • 2013}

11. Zolya E. Dobycha. Perevod s frantsuzskogo T. Irinovoi. $\backslash$ Rugon-Makkary. Emil' Zolya. Sobranie sochinenii v 18 tomakh. Tom 1. M., "Pravda", 1957. Pod redaktsiei A. Puzikova.

12. Kant I. Metafizika nravov. Ch. 2 // Soch. v 6 t. T. 4, ch. 2.-M., 1965.

13. Mitroshenkov O.A. Filosofiya: Uchebnik / Pod red. prof. O.A. Mitroshenkova.-M. : Gardariki, 2002. $-655 \mathrm{~s}$.

14. Potapova Z. M. Gi de Mopassan // Istoriya vsemirnoi literatury: V 8 tomakh / AN SSSR;
In-t mirovoi lit. im. A. M. Gor'kogo. - M.: Nauka, 1983-1994. - Na titl. 1. izd.: Istoriya vsemirnoi literatury: v 9 t. T. 7. - 1991. - S. 299-308.

15. Simkina N.N. Kul'turologiya : uchebnoe posobie / N.N. Simkina. - Bryansk: Izdatel'ctvo Bryanskogo gosudarstvennogo tekhnicheskogo universiteta, 2004. - $268 \mathrm{~s}$..

16. Khlodovskii R. Rim v mire Gogolya Inostrannaya literatura, 1984, №12, ss. $203-210$.

17. Shpengler O. Zakat Evropy. Geshtal't i deistvitel'nost'. Izd. Mysl', 1998, 663 s. 